Article

\title{
Pilot-Scale Removal of Arsenic and Heavy Metals from Mining Wastewater Using Adsorption Combined with Constructed Wetland
}

\author{
Ha T. H. Nguyen ${ }^{1} \oplus$, Bien Q. Nguyen ${ }^{1}$, Thuy T. Duong ${ }^{2}$, Anh T. K. Bui ${ }^{3}$, Hang T. A. Nguyen ${ }^{2}$, \\ Ha T. Cao ${ }^{1}$, Nhuan T. Mai ${ }^{1}$, Khai M. Nguyen ${ }^{1}{ }^{\mathbb{D}}$, Thuy T. Pham ${ }^{1}$ and Kyoung-Woong Kim ${ }^{4, *}$ \\ 1 VNU University of Science, Vietnam National University, 334 Nguyen Trai, Ha Noi 10053, Vietnam; \\ hoangha.nt@vnu.edu.vn (H.T.H.N.); vio.quocbien@gmail.com (B.Q.N.); caotheha@gmail.com (H.T.C.); \\ nhuanmt@vnu.edu.vn (N.T.M.); khainm@vnu.edu.vn (K.M.N.); phamthithuy@hus.edu.vn (T.T.P.) \\ 2 Vietnam Japan University, Vietnam National University, Luu Huu Phuoc, Hanoi 10053, Vietnam; \\ thuy.dgth@gmail.com (T.T.D.); nta.hang@vju.ac.vn (H.T.A.N.) \\ 3 Institute of Environmental Technology, Vietnam Academy of Science and Technology, 18 Hoang Quoc Viet, \\ Ha Noi 10072, Vietnam; buianh7811@gmail.com \\ 4 International Environmental Research Institute (IERI) and Gwangju Institute of Science \& Technology (GIST), \\ Gwangju 61005, Korea \\ * Correspondence: kwkim@gist.ac.kr; Tel.: +82-62-715-3391
}

Received: 14 May 2019; Accepted: 20 June 2019; Published: 23 June 2019

\begin{abstract}
This study was conducted to assess the removal of arsenic (As) and heavy metals from mining wastewater by the combination of adsorption, using modified iron-ore drainage sludge, and horizontal-subsurface-flow constructed wetland with common reed (Phragmites australis). The pilot-scale experiment with a constant flow rate of $5 \mathrm{~m}^{3} /$ day was operated for four months using real wastewater from $\mathrm{a} \mathrm{Pb}-\mathrm{Zn}$ mine in northern Vietnam. Atomic absorption spectroscopy was used for elemental analysis in wastewater and plant. X-ray diffraction (XRD), surface charge measurements (by a particle charge detector (PCD)), Fourier-transform infrared (FTIR), and surface area Brunauer-Emmet-Teller (BET) measurements were performed to determine the characteristics of the adsorbent. The results showed that the average removals of $\mathrm{As}, \mathrm{Mn}, \mathrm{Cd}, \mathrm{Zn}$, and $\mathrm{Pb}$ by the combined system with limestone substrate during four months were $80.3 \%, 96.9 \%, 79.6 \%, 52.9 \%$, and $38.7 \%$, respectively. The use of another constructed wetland substrate, laterite, demonstrated better removal efficiency of As than limestone. The concentrations of As and heavy metals in the effluent were lower than the limits established by the QCVN 40:2011/BTNMT for industrial wastewater, which indicated the feasibility of combining adsorption and constructed wetland for the treatment of mining wastewater.
\end{abstract}

Keywords: adsorbent; arsenic; constructed wetland; heavy metal; mining wastewater; removal

\section{Introduction}

Mining activities release large amounts of solid wastes and wastewater into the surrounding environment. Wastewater from mineral exploitation and processing is characterized by high concentrations of arsenic (As) and heavy metals (e.g., manganese (Mn), copper $(\mathrm{Cu})$, lead $(\mathrm{Pb})$, and zinc $(\mathrm{Zn})$ ) that may induce severe environmental problems and various risks to exposed humans and ecosystem [1-3]. A variety of treatment technologies have been extensively studied and applied, including adsorption, membrane filtration [4], coagulation [5], ion-exchange [6], electrocoagulation [7], and biological processes [8]. Naturally, any technology possesses both advantages and limitations, considering treatment effectiveness, installation, operational and maintenance cost, further treatment of secondary wastes, technical requirements, and time and space requirements $[9,10]$. 
Adsorption is considered a cost-effective method [11,12] when using adsorbents that require little processing or are industrial wastes or by-products [13]. The use of mining wastes as adsorbents is considered an environment-friendly technique with double benefits, as it allows to treat both solid wastes and contaminated water and to approach the ideal goal of waste-free production $[14,15]$. However, adsorption can be reversible, and the removal efficiency depends on the type of adsorbents and substances to be removed [16]. Therefore, the combination of adsorption with other technologies may be required for the effective treatment of wastewater contaminated with multiple heavy metals.

Constructed wetland (CW) planted with macrophytes has been widely applied for the treatment of municipal, industrial, and urban runoff wastewaters [17], considering their remediation effectiveness, simple operation [18,19], and benefits for ecosystem services [20]. Phragmites australis (common reed) has been commonly used in CW systems because of its cosmopolitan distribution, ease of growing, and ready adaptation to different environments $[19,21]$. In addition, this plant can accumulate heavy metals in its biomass [19] and is highly adaptable to many substrates, such as coke, gravel [22], blast furnace slag, ceramsite, vermiculite, gravel, paddy soil, red soil, turf [23], zeolite, limestone, and cocopeat [24].

Cho Don is the largest $\mathrm{Pb}-\mathrm{Zn}$ mine in Vietnam. Commencing operation in the 18th century, it has released considerable amounts of wastewater contaminated with As and heavy metals (e.g., $\mathrm{Pb}$ and $\mathrm{Mn}$ ) into the surrounding environment [25]. The remediation cost is of high importance in the selection of proper technologies for the removal of As and heavy metals from wastewater in this mine. Iron-ore sludge from a processing area near the $\mathrm{Cho} \mathrm{Don} \mathrm{Pb}-\mathrm{Zn}$ mine was reported to be a promising adsorbent to remove As and heavy metals from water [26]. P. australis was observed to grow naturally along the main stream near Cho Don mine, and limestone was also found in the area. The use of the plant and these materials as adsorbent and substrate in the CW system may be an environment-friendly approach that reduces the transportation cost for wastewater treatment. In a laboratory experiment, the combination of an adsorbent modified from this iron-ore sludge and CW was reported to effectively remove As and heavy metals from synthetic solutions [27]. However, at pilot scale, the feasibility of this combined system has not been previously assessed using real wastewater.

The present study aimed to evaluate the potential of using an adsorbent and CW in removing As and heavy metals from the wastewater of $\mathrm{Cho} \mathrm{Don} \mathrm{Pb}-\mathrm{Zn}$ mine.

\section{Materials and Methods}

\subsection{Adsorbent, Plant, Substrate, and Mining Wastewater}

This study used the same adsorbent as that introduced in previous research (SBC2-400-10S) [27]. This adsorbent (SBC2-400-10S) was of $2 \mathrm{~mm}$ diameter. The characteristics of this adsorbent are shown in Table 1. The obtained spectra by FTIR measurement of SBC2-400-10S showed peaks at $3610 \mathrm{~cm}^{-1}$, which were probably from $\mathrm{OH}$ bending. In addition, the peaks at 1031 and $778 \mathrm{~cm}^{-1}$ indicated the presence of $\mathrm{Si}-\mathrm{O}-\mathrm{Si}$ and $\mathrm{Si}-\mathrm{OH}$ groups.

$P$. australis, more than $1 \mathrm{~m}$ high and approximately $1 \mathrm{~mm}$ in diameter, was collected along the main stream near the $\mathrm{Cho}$ Don $\mathrm{Pb}-\mathrm{Zn}$ mine. The plants were cut to keep the belowground parts and $50 \mathrm{~cm}$ stems and washed well before transplanting in the CWs. P. australis was transplanted and grown in the CWs for a period of 3 months, before starting the operation of the combined system. Laterite and limestone were used as substrates in the CW system. The main minerals of laterite and limestone in the present study are shown in Table 1. 
Table 1. Characteristics of adsorbent and substrates. BET: Brunauer-Emmet-Teller, PCD: Particle Charge Detector.

\begin{tabular}{|c|c|c|c|c|}
\hline \multirow{2}{*}{\multicolumn{2}{|c|}{ Material Characteristics }} & \multirow{2}{*}{$\begin{array}{c}\text { Adsorbent } \\
\text { (SBC2-400-10S) }\end{array}$} & \multicolumn{2}{|c|}{ Substrates } \\
\hline & & & Limestone & Laterite \\
\hline \multirow{8}{*}{$\begin{array}{l}\text { Mineral } \\
\text { composition (\%) }\end{array}$} & Quartz & $43 *$ & - & $39 * *$ \\
\hline & Muscovite & $13 *$ & - & - \\
\hline & Illite & $13 *$ & - & $2^{* *}$ \\
\hline & Kaolinite & $12 *$ & - & $36^{* *}$ \\
\hline & Hematite & $7 *$ & - & $7^{* *}$ \\
\hline & Goethite & $4^{*}$ & - & $15^{* *}$ \\
\hline & Calcite & - & 14 & - \\
\hline & Ankerite & - & 86 & - \\
\hline \multicolumn{2}{|c|}{$\operatorname{BET}\left(\mathrm{m}^{2} / \mathrm{g}\right)$} & 39.5 & - & - \\
\hline \multicolumn{2}{|c|}{$\mathrm{PCD}\left(\mathrm{mmol}_{\mathrm{C}(-)} \cdot \mathrm{kg}^{-1}\right)$} & 88.7 & - & $52^{* *}$ \\
\hline
\end{tabular}

Wastewater in the present study had these characteristics: $\mathrm{pH} 7.3$, alkalinity $104 \mathrm{mg} / \mathrm{L}$, electrical conductivity (EC) $776 \mu \mathrm{S} / \mathrm{cm}$, total dissolved solids (TDS) $624 \mathrm{mg} / \mathrm{L}$, total suspended solids (TSS) $42.8 \mathrm{mg} / \mathrm{L}$, biological oxygen demand $\left(\mathrm{BOD}_{5}\right) 3.9 \mathrm{mg} / \mathrm{L}$, and chemical oxygen demand (COD) $8.1 \mathrm{mg} / \mathrm{L}$. The TSS, BOD ${ }_{5}$, and COD values were lower than the maximum allowable limit (MAL) for wastewater for both category A (QCVN40:2011-BTNMT-A: water source for domestic water supply [29]) and category B (QCVN40:2011-BTNMT-B: water source not for domestic water supply [29]). The concentrations of $\mathrm{Mn}, \mathrm{Zn}, \mathrm{Cd}, \mathrm{Pb}$, and $\mathrm{As}$ in wastewater before entering the combined system during 4 months of investigation varied and were $2.56-3.75,0.81-1.33,0.33-0.63,0.37-0.65$, and $0.22-0.30 \mathrm{mg} / \mathrm{L}$, respectively. The concentrations of $\mathrm{Mn}, \mathrm{Cd}, \mathrm{Pb}$, and As exceeded the MAL for wastewater for both categories A and B [29]).

\subsection{System Set-Up and Operation}

The combined system was set up near the processing plant of Cho Don $\mathrm{Pb}-\mathrm{Zn}$ mine, in northern Vietnam. Wastewater from the processing area that passed through two settling reservoirs was automatically pumped at a constant rate $\left(5 \mathrm{~m}^{3} /\right.$ day) into the treatment system, before discharging into a stream (Figure 1).

The treatment system consisted of eight modules with different functions: settling tank (module MD1), adsorbent tank (MD2), and CWs (MD3-8) (Figure 1 and Table 2). MD2 was designed to include two compartments with $0.71 \mathrm{~m}^{3}$ of total working volume and $30 \mathrm{~min}$ of retention time. Water flowed from MD1 to the first compartment of MD2, before discharging into the second compartment. Approximately $138 \mathrm{~kg}$ of adsorbent (SBC2-400-10S) was added to the second compartment. The constructed wetlands, which received wastewater from MD2, included six modules (MD3-8). Figure $1 \mathrm{~b}$ and Table 2 show the size parameters of these tanks. The grain size of the substrates (limestone and laterite) was set to be approximately $2-4 \mathrm{~cm}$, the pore volume was $45 \%$, and the safety factor was 2\%. Wastewater from MD6 was equally distributed into MD7 and MD8. Limestone was used as a substrate material for the growth of P. australis in MD3, MD4, MD5, MD6, and MD7, whereas laterite was used in MD8. The density of $P$. australis transplanted in CW was approximately 45 plants $/ \mathrm{m}^{2}$. In this study, hydraulic retention time (HRT) was set to be $46 \mathrm{~h}$, according to previous laboratory experiments. The design of subsurface-flow CWs was calculated by the following equations: Total surface area of CW (S) $\left(\mathrm{m}^{2}\right)$ :

$$
\begin{aligned}
S & =S_{M D 3}+S_{M D 4}+\ldots+S_{M D 8} \\
& =(4 \times 4.1)+(2 \times 2.05)=20.5 \mathrm{~m}^{2}
\end{aligned}
$$




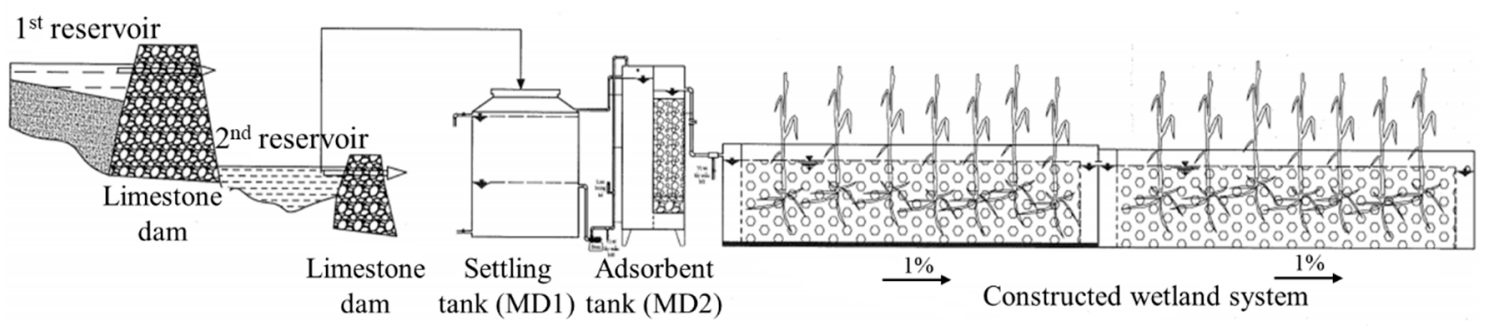

(a)

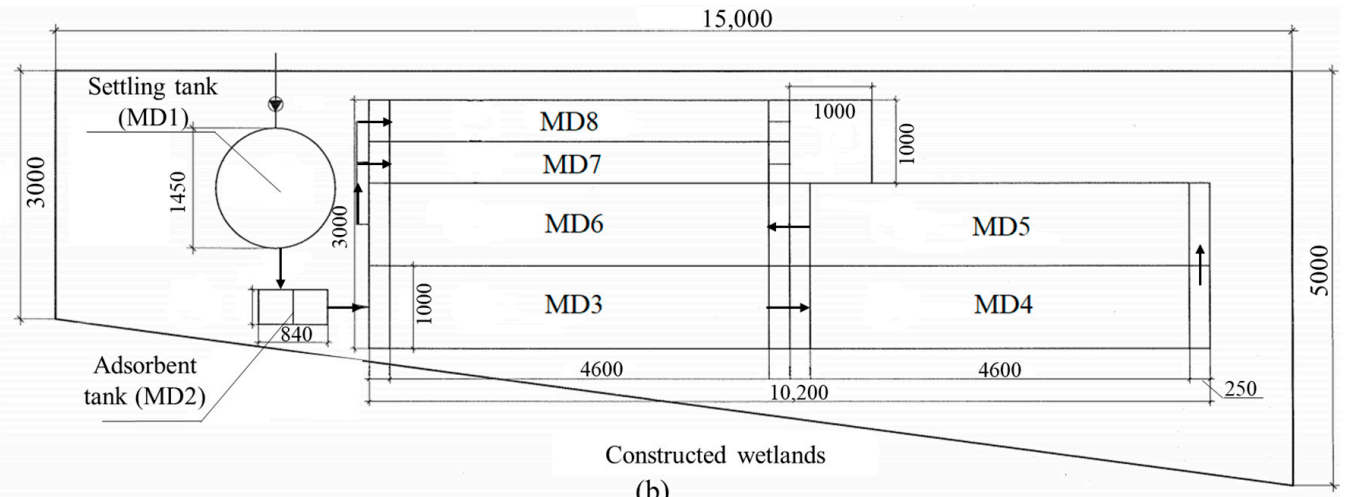

(b)

Figure 1. (a) Cross section, and (b) design parameters of the treatment system.

Table 2. Size parameters of modules of the treatment system. MD1: settling tank, MD2: adsorbent tank, MD3-MD8: constructed wetlands modules.

\begin{tabular}{cccc}
\hline Module & $\begin{array}{c}\text { Filtration Materials } \\
\text { (Substrates) }\end{array}$ & $\begin{array}{c}\text { Dimension }(\text { Height }(\mathbf{m m}) \times \text { Width } \\
(\mathbf{m m}) \times \text { Length) }(\mathbf{m m}) \mathbf{)}\end{array}$ & Working Volume $\left.\mathbf{( m}^{\mathbf{3}}\right)$ \\
\hline MD1 & & $2000 \times 1500 \times 1500$ & 4.5 \\
MD2 & SBC2-400-10S & $2000 \times 420 \times 840$ & 0.71 \\
MD3-MD6 & Limestone & $1000 \times 1000 \times 4100$ & 4.1 \\
MD7 & Limestone & $1000 \times 500 \times 4100$ & 2.05 \\
MD8 & Laterite & $1000 \times 500 \times 4100$ & 2.05 \\
\hline
\end{tabular}

Total working volume of $\mathrm{CW}\left(V_{t}\right)\left(\mathrm{m}^{3}\right)$ :

$$
V_{t}=V \times \varphi=\left(V_{M D 3}+\ldots+V_{M D 8}\right) \times 47 \%=9.64 \mathrm{~m}^{3}
$$

Velocity of CW $\left(v_{f}\right)$ :

$$
\begin{aligned}
v_{f} & =Q \times \frac{1}{A_{s}}=5 \times \frac{1}{1 \times 1 \times 47 \%} \\
& =10.6 \mathrm{~m}^{3} / \mathrm{m}^{2} \cdot \text { day }
\end{aligned}
$$

Total surface loading of CW $\left(L_{\mathrm{s}}\right)$ :

$$
L_{\mathrm{s}}=Q \times \frac{1}{S}=5 \times \frac{1}{20.5}=0.244 \mathrm{~m}^{3} / \mathrm{m}^{2} \text { day }
$$

where $Q$ is the flow rate $\left(\mathrm{m}^{3} /\right.$ day), $\varphi$ is the porosity of the substrate added with the safety factor (\%), $\mathrm{A}_{\mathrm{s}}$ is the area of the cross section of CWs with $\varphi=47 \%, 1 \mathrm{~m}$ high, and $1 \mathrm{~m}$ wide.

\subsection{Sampling}

Water samples before running into the treatment system and after flowing through each module (MD1-8) were collected on the first day, after 1, 2, and 3 weeks, and after 1, 1.5, 2, 2.5, 3, and 4 months of the combined system operation. In total, 90 samples were collected. 
Adsorbent, P. australis, and substrate samples (0.8-1.0 kg of each) were collected before, and 4 months after the system operation. Each sample was collected by combining 3-5 aliquots of adsorbent, P. australis, or substrate. The number of collected adsorbent samples was six. From each module of CWs, one plant sample was collected. The number of collected plant samples was 12. In addition, six substrate samples from the CWs, including three limestone and three laterite samples, were also collected.

\subsection{Analytical Methods}

P. australis samples were separated into belowground (roots and rhizomes) and aboveground biomass (stems + leaves) parts and washed well with deionized water. The plant, adsorbent, and substrate samples were dried in an oven at $80{ }^{\circ} \mathrm{C}$ until the weight was constant and then ground into fine powder. In total, $100 \mathrm{mg}$ of adsorbent was digested with an $\mathrm{HNO}_{3} / \mathrm{HF} / \mathrm{HCl}$ mixture (1:1:2, $v / v)$. The plant samples were digested with $3 \mathrm{~mL}$ of $\mathrm{HNO}_{3}$ and $0.6 \mathrm{~mL} \mathrm{H}_{2} \mathrm{O}_{2}$ for each $100 \mathrm{mg}$ aliquot. The concentrations of five target metals (i.e., $\mathrm{Mn}, \mathrm{Zn}, \mathrm{Cd}, \mathrm{Pb}$, and $\mathrm{As}$ ) in the adsorbent and plant samples were determined by atomic absorption spectroscopy (AAS, Agilent 240FS with hydride generation accessory VGA77).

Surface charge, Fourier-transform infrared (FTIR), and surface area measurements were performed for the adsorbent. Surface charge was determined using a particle charge detector (PCD, Mütek 05). A FTIR Spectrometer (Nicolet iS5, Thermo Scientific) was used for the measurement of FTIR. Surface area was determined by Gemini VII 2390 surface area analyzer (Micromeritics). The Brunauer-Emmet-Teller (BET) method was used to calculate the specific surface area.

The mineral composition of the substrates (e.g., limestone and laterite) was determined using X-ray diffraction (XRD, D5005, Siemens) on powder samples. The XRD was equipped with a Cu $(\mathrm{K} \alpha 1,2)$ target operated at $40 \mathrm{kV}$ and $30 \mathrm{~mA}$ with a setting of $2 \theta=(3-70)^{\circ}$, in steps of $0.02^{\circ}$.

All analyses were performed at the Key Laboratory of Geo-environment and Climate Change Response, Vietnam National University, Hanoi, Vietnam.

\subsection{Calculation of Metal Removal and Accumulation}

The removal efficiency (\%) for the target metal was obtained using the following equation:

$$
\text { Removal efficiency }(\%)=\frac{C_{i}-C_{\text {effluent }}}{C_{i}} \times 100 \%
$$

where $C_{i}$ is the concentration of each metal in wastewater before entering MD1, and $C_{e f f l u e n t}$ is the concentration of each metal in wastewater after discharging from a target module (MD1, MD2, MD7, and MD8).

The amount of each metal removed from wastewater $\left(C_{r}\right)$ by the adsorbent or CWs was calculated by the following equation:

$$
C_{r}(\mathrm{mg})=\left(C_{\text {influent }}(\mathrm{mg} / \mathrm{L})-C_{\text {effluent }}(\mathrm{mg} / \mathrm{L}) \times T(\text { days }) \times H L R(\mathrm{~L} / \text { day })\right.
$$

where $C_{\text {influent }}$ and $C_{\text {ef fluent }}$ are the concentrations of each metal in wastewater before and after entering each module (adsorbent tank or CW), respectively, $\mathrm{T}$ is the duration of treatment system operation, and HLR represents the hydraulic loading rate.

The amount of each metal adsorbed by the sorbent or accumulated in $P$. australis $\left(C_{a}\right)$ was determined by the following equation:

$$
C_{a}(\mathrm{mg})=\left(C(\mathrm{mg} / \mathrm{kg})-C_{o}(\mathrm{mg} / \mathrm{kg})\right) \times m(\mathrm{~kg})
$$

where $C_{o}$ and $C$ are the concentrations of metal in the adsorbent or $P$. australis before and after the experiment, respectively, and $\mathrm{m}$ is the total mass of adsorbent or P. australis in the experiment. 


\section{Results}

\subsection{Removal of As and Heavy Metals from Mining Wastewater}

Figure 2 shows the concentrations of As and heavy metals in wastewater before entering the treatment system (initial wastewater $-C_{i}$ ) and in the effluent of different modules during 4 months of operation. A decreasing trend in the concentrations of $\mathrm{As}, \mathrm{Mn}, \mathrm{Zn}, \mathrm{Cd}$, and $\mathrm{Pb}$ in the effluent after running through different modules during 4 months of system operation was observed. The removal efficiencies of As and heavy metals by the adsorbent tank were higher than those by the settling tank and CWs (Table 3).

Table 3. Average removal efficiency (\%) of As and heavy metals from wastewater in 4 months of operation.

\begin{tabular}{cccccc}
\hline Moduls & As & Mn & Zn & Cd & Pb \\
\hline MD1 & 9.56 & 2.64 & 27.2 & 13.7 & 28.1 \\
MD2 & 49.6 & 54.3 & 50.0 & 43.9 & 16.0 \\
MD3-7 & 30.7 & 42.6 & 2.87 & 35.7 & 22.7 \\
MD3-7 * & 75.1 & 98.8 & 30.2 & 83.7 & 42.8 \\
MD3-6 + MD8 & 34.7 & 32.1 & 2.39 & 31.9 & 18.3 \\
MD2 + MD3-7 & 80.3 & 96.9 & 52.9 & 79.6 & 38.7 \\
MD1 + MD2 + MD3-7 & 89.9 & 99.5 & 80.1 & 93.3 & 66.8
\end{tabular}

MD1: settling tank, MD2: adsorbent tank, MD3-7: constructed wetland with limestone substrate, MD8: constructed wetland with laterite substrate. * Removal efficiency calculated by using the concentration of metal in the influent before entering MD3.

The concentrations of As in MD2 effluent (adsorbent tank) met the MAL for category B [29] during the first month and exceeded the MAL from the second month to the end of the experiment. However, the concentrations of As in the effluents of CWs (MD3-8) were lower than the MAL for category A [29]. The average removal efficiencies of As by MD1, MD2, MD3-7 (limestone substrate), and MD3-6 + MD8 were 9.56, 49.6, 30.7, and 34.7\%, respectively (Table 3). A decreasing trend of As removal by the adsorbent was observed from the beginning to the end of the experiment (Figure 2). The removal efficiency of As by CWs with laterite substrate (MD8) was higher than that with limestone (MD7) (Figure 2). High removal of As by laterite was possibly due to the additional adsorption of As by goethite minerals (39\%) in the laterite substrate in the present study [28]. Allende et al. [24] reported the higher removal efficiency of As by CW (99.9\%), possibly due to the longer retention time and the use of zeolite as a substrate.

The average concentration of $\mathrm{Mn}$ in the influent was $3.11 \mathrm{mg} / \mathrm{L}$, which was approximately sixand three-fold higher than the MAL [29] for category A and B, respectively. During the first day of the experiment, the concentrations of Mn in MD2 effluent were lower than the MAL for category B, and after that, exceeded the MAL. However, Mn concentrations in the effluents of both MD7 and MD8 were lower than the MAL for category B [29], which demonstrated the efficiency of metal removal by the CWs. The removal efficiency of Mn by the adsorbent was gradually reduced during the experiment (Figure 2), implying the saturation of the active sites of the adsorbent and the attainment of equilibrium [30]. The average removal efficiencies of Mn by MD1, MD2, MD3-7, and MD3-6 + MD8 were 2.64, 54.3, 42.7, and 32.1\%, respectively (Table 3). The removal efficiency of Mn by the treatment system (settling tank, adsorbent tank, and CWs with limestone substrate) was $99.5 \%$.

The concentrations of $\mathrm{Zn}$ in the influent were lower than the MAL for category A [29] and were decreased rapidly by the adsorbent (MD2) (average of 50.0\% during 4 months) (Table 3, Figure 2). The concentrations of Cd in MD2 effluent were higher than the MAL for category B [29] and were continuously decreased by CWs, meeting the regulation category A (limestone substrate) and category $\mathrm{B}$ (laterite substrate) (Figure 2). The results of this study also showed a higher average removal of $\mathrm{Cd}$ by MD2 (44.0\%) than that by CWs (35.7\%) (Table 3). 
$\mathrm{Pb}$ demonstrated lower removal efficiencies by the adsorbent and $\mathrm{CWs}$ than $\mathrm{As}, \mathrm{Mn}, \mathrm{Zn}$, and $\mathrm{Cd}$ (Figure 2). The concentrations of $\mathrm{Pb}$ in the influent were slightly higher than the MAL for category B [29] and decreased, meeting the regulation for category B [29], in the effluent of MD7 and MD8. The average removal efficiency of $\mathrm{Pb}$ by the treatment system during 4 months of operation was $66.7 \%$ (Table 3). The removal efficiency of $\mathrm{Pb}$ in this study was lower than those reported by Chen et al. [22] using coke and gravel substrates, possibly due to the CW designs and different substrates.

After 4 months of system operation, the average removal efficiency of As and heavy metals by the treatment system (settling tank, adsorbent tank, and CWs with limestone substrate) were in the following order: $\mathrm{Mn}(99.5 \%)>\mathrm{Cd}(93.3 \%)>$ As $(89.9 \%)>\mathrm{Zn}(80.1 \%)>\mathrm{Pb}(66.7 \%)$. In addition, the results of this study demonstrated that CWs with laterite substrate showed higher removal efficiency of As than CWs with limestone, whereas the latter was more efficient for $\mathrm{Mn}, \mathrm{Pb}$, and $\mathrm{Cd}$ removal. This result indicates the significance of the selection of different substrates for the removal of targeted metals.

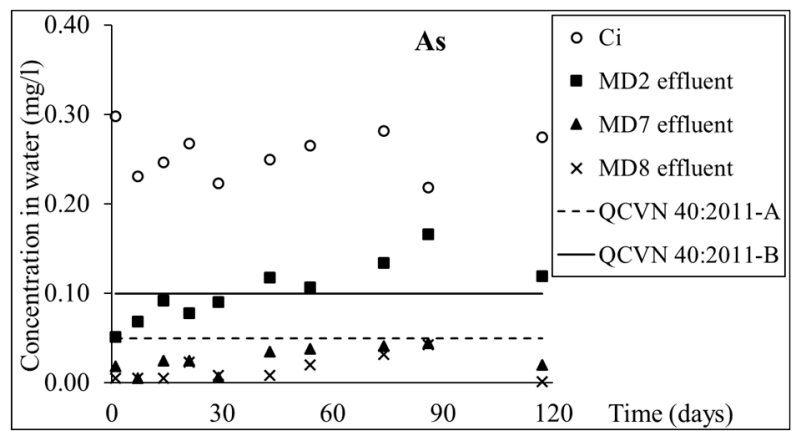

(a)

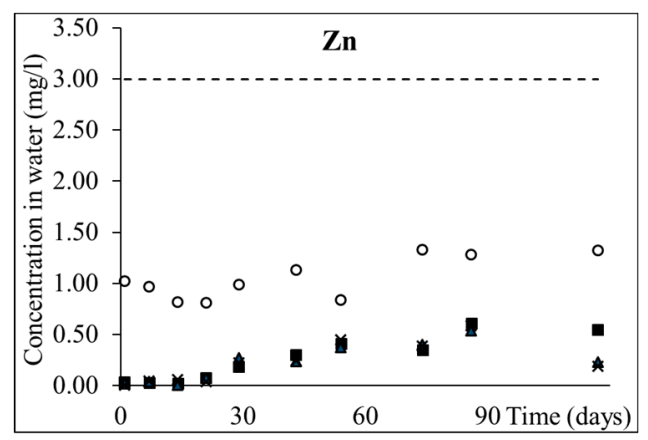

(c)

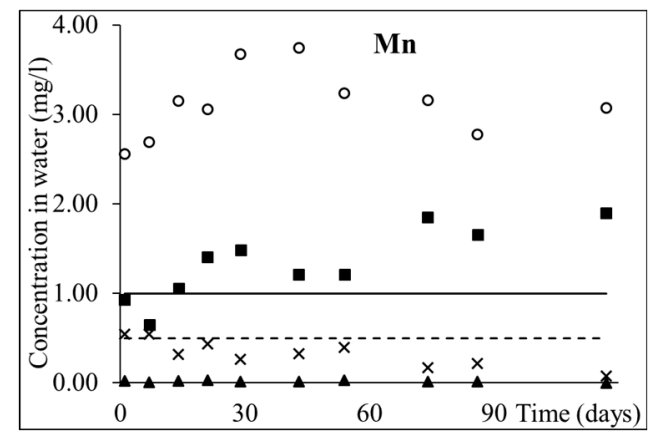

(b)

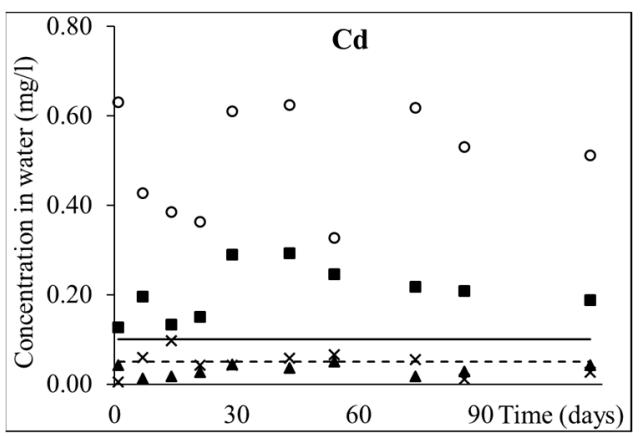

(d)

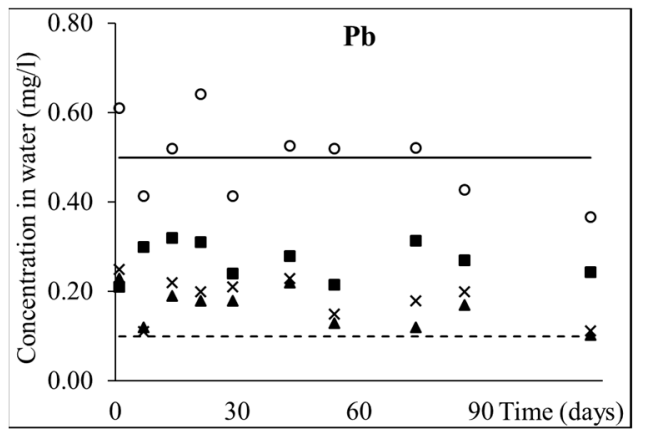

(e)

Figure 2. Concentrations of (a) As, (b) Mn, (c) $\mathrm{Zn},(\mathbf{d}) \mathrm{Cd}$, and (e) $\mathrm{Pb}$ in wastewater before entering the treatment system (Ci) and in the effluents from the adsorbent tank (MD2), constructed wetland with limestone substrate (MD3-MD7), and constructed wetland with laterite substrate (MD8).

The removal efficiencies of $\mathrm{As}, \mathrm{Mn}, \mathrm{Zn}$, and $\mathrm{Pb}$ in the present study were lower than those reported by Ha and Anh [27] who used the same adsorbent (SBC2-400-10S) and horizontal-subsurface-flow CWs with limestone substrate and higher concentrations of these metals in the influent (Tables 3 and 4). 
The difference may be due to the fact that the present study used the real wastewater released from a $\mathrm{Pb}-\mathrm{Zn}$ mine, whereas the water in the previous study was prepared by the dilution of nitrate metal salts in a laboratory experiment. This result implies a variation of metal removal efficiencies when designing pilot and full-scale treatment systems on the basis of laboratory experiments.

The removal efficiencies of As and heavy metals by CWs using the data of the influent before entering the CWs (MD3) were calculated for comparison with previous studies. The removal efficiency of Zn by CWs in the present study (Table 3) was higher than that reported by Alessio et al. [31] using gravel substrates. However, Chen et al. [22], Ha and Anh [27], Yeh et al. [32], and Liu et al. [33] reported higher removal efficiency than those determined in this study. The removal efficiencies of Cd in this study were higher than those reported by Kumari and Tripathi [34] and Scholes et al. [35] and lower than those by Liu et al. [33]. The results of this study also demonstrated lower removal efficiencies of $\mathrm{Pb}$ compared to those reported in some studies, such as Chen et al. [22], Ha and Anh [27], Scholes et al. [35], Liu et al. [33], and those in Table 4. The type of wetland (i.e., surface-flow, horizontal-subsurface flow, and vertical-subsurface flow), substrates, retention time, hydraulic loading rate, and concentrations of metals in the influent may result in differences of metal removal efficiencies (Table 4).

\subsection{Accumulation of As and Heavy Metals in the Adsorbent}

The concentrations of $\mathrm{Mn}, \mathrm{Zn}, \mathrm{Pb}, \mathrm{Cd}$, and $\mathrm{As}$ in the adsorbent before the experiment were 1460, $930,245,170$, and $67 \mathrm{mg} / \mathrm{kg}$, respectively; after 4 months of the experiment, they increased to 3930 , $1870,512,420$, and $289 \mathrm{mg} / \mathrm{kg}$ (Figure 3). The adsorption of metals by the adsorbent in this study can be explained by the results of specific surface area measurements (BET method), surface charge density measurements (by PCD), clay minerals presence (e.g., kaolinite and illite) [36], presence of high amounts of silica (Si-OH and $\mathrm{Si}-\mathrm{O}-\mathrm{OH}$ ) [37,38], and $\mathrm{OH}$ bending [37,39]. In addition, the presence of hematite (7\%) and goethite (4\%) may result in the adsorption of As by the adsorbent (SBC2-400-10S) [40,41]. However, the adsorption capacities of SBC2-400-10S for heavy metals in this study were lower than those reported in previous batch experiments using activated carbon $(\mathrm{Pb}=20.7 \mathrm{mg} / \mathrm{g} ; \mathrm{Cd}=17.8 \mathrm{mg} / \mathrm{g}$; $\mathrm{Zn}=19.9 \mathrm{mg} / \mathrm{g})$ [42], montmorillonite $(\mathrm{Pb}=31.1 \mathrm{mg} / \mathrm{g} ; \mathrm{Cd}=30.7 \mathrm{mg} / \mathrm{g})$ [43], and modified red mud (As $=1.08 \mathrm{mg} / \mathrm{g}$ ) [44]. The lower adsorption capacities of SBC2-400-10S compared with those of other adsorbents were possibly due to the characteristics of the adsorbents, the concentrations of As and heavy metals, and the use of real mining wastewater in the present study.

The total amounts of $\mathrm{Mn}, \mathrm{Zn}, \mathrm{Cd}, \mathrm{Pb}$, and As adsorbed to SBC2-400-10S after 4 months were $341,130,34.5,36.8$, and $30.6 \mathrm{~g}$, respectively. The amounts of $\mathrm{Mn}, \mathrm{Zn}, \mathrm{Cd}, \mathrm{Pb}$, and As removed by the adsorbent tank were 986, 292, 131, 53.5, and $74.2 \mathrm{~g}$, respectively. The higher amounts of metals removed by the adsorbent tank compared with those adsorbed to SBC2-400-10S indicated the additional removal of heavy metals by other processes, such as co-precipitation or inner-sphere and outer-sphere complexation [45]. After reaching equilibrium, the adsorbents can be treated by desorption, recovering As and heavy metals [46] by using chemical substances [47,48], or be used in brick and cement production. However, further studies need to be performed to assess the possibility of metal leaching from the adsorbent. 
Table 4. Constructed wetland designs, removal efficiencies, and concentrations of As and heavy metals in P. australis.

\begin{tabular}{|c|c|c|c|c|c|c|c|c|c|c|c|}
\hline \multirow{2}{*}{ Metals } & \multirow{2}{*}{ Authors } & \multirow{2}{*}{$\begin{array}{l}\text { Type of } \\
\text { Wetland }\end{array}$} & \multirow{2}{*}{ Substrates } & \multirow{2}{*}{ Length $\times$ width $\times$ depth $(m)$} & \multirow{2}{*}{$\begin{array}{l}\text { Retention } \\
\text { Time }\end{array}$} & \multirow{2}{*}{$\begin{array}{l}\text { Hydraulic } \\
\text { Loading } \\
\text { Rate }\end{array}$} & \multirow{2}{*}{$\begin{array}{c}\text { Operation } \\
\text { Duration } \\
\text { (Months) }\end{array}$} & \multirow{2}{*}{$\begin{array}{c}\text { Influent } \\
\text { Concentration } \\
(\mathrm{mg} / \mathrm{L})\end{array}$} & \multirow{2}{*}{$\begin{array}{l}\text { Removal } \\
\text { Efficiency } \\
(\%)\end{array}$} & \multicolumn{2}{|c|}{$\begin{array}{c}\text { Metal Content in P. australis } \\
(\mathrm{mg} / \mathrm{kg}-\mathrm{DW})\end{array}$} \\
\hline & & & & & & & & & & $\begin{array}{l}\text { Belowground } \\
\text { Biomass }\end{array}$ & $\begin{array}{l}\text { Aboveground } \\
\text { Biomass }\end{array}$ \\
\hline \multirow{7}{*}{ As } & This study & HSSF & $\begin{array}{l}\text { Limestone } \\
\text { Laterite }\end{array}$ & $1 \times 1 \times 4.1+1 \times 0.5 \times 4.1$ & $2 \mathrm{~d}$ & $5 \mathrm{~m}^{3} / \mathrm{d}$ & 4 & 0.1 & $\begin{array}{l}75.1 \\
86.0\end{array}$ & 21.9 & 17.8 \\
\hline & [24] & HSSF & Zeolite & $0.6 \times 0.2 \times 0.65$ & $11 \mathrm{~d}$ & $30 \mathrm{~mm} / \mathrm{d}$ & 5.5 & 2.6 & 99.9 & 0.00286 & 0.00234 \\
\hline & {$[27]^{*}$} & $\begin{array}{l}\text { SF } \\
\mathrm{HSSF}\end{array}$ & $\begin{array}{c}\text { Soil } \\
\text { Limestone }\end{array}$ & $\begin{array}{l}1.2 \times 0.23 \\
1.2 \times 0.28\end{array}$ & $2 \mathrm{~d}$ & $0.05 \mathrm{~m}^{3} /$ day & 1 & 0.4 & $\begin{array}{l}80.5 \\
83.1\end{array}$ & - & - \\
\hline & [49] & - & Sand & $1 \times 0.6$ & $10 \mathrm{~d}$ & - & - & 0.2 & - & 119.55 & 6.36 \\
\hline & [50] & VSSF & Sand & $1 \times 1 \times 1.5$ & $2-3 w$ & $28 \mathrm{~mm} / \mathrm{d}$ & 24 & & - & 1.65 & 0.58 \\
\hline & [51] & HSSF & - & - & - & - & - & - & - & 4.95 & 0.18 \\
\hline & [52] & - & Sediment & - & - & - & - & 37.6 & - & $1.2-2.4$ & $0.1-0.6$ \\
\hline \multirow{7}{*}{ Mn } & This study & HSSF & Limestone & $1 \times 1 \times 4.1+1 \times 0.5 \times 4.1$ & $2 \mathrm{~d}$ & $5 \mathrm{~m}^{3} /$ day & 4 & 1.34 & 98.8 & 2200 & 506 \\
\hline & {$[27]^{*}$} & $\begin{array}{l}\text { SF } \\
\text { HSSF }\end{array}$ & $\begin{array}{c}\text { Soil } \\
\text { Limestone }\end{array}$ & $\begin{array}{l}1.2 \times 0.23 \\
1.2 \times 0.28\end{array}$ & $2 \mathrm{~d}$ & $0.05 \mathrm{~m}^{3} /$ day & 1 & 4 & $\begin{array}{l}91.2 \\
94.1\end{array}$ & - & - \\
\hline & [51] & HSSF & - & - & - & - & - & - & - & 266 & 175 \\
\hline & [52] & - & Sediment & - & - & - & - & 2606 & - & $264.7-1178$ & $193.3-361.9$ \\
\hline & {$[53]$} & VSSF & Goetextile & $12.5 \times 30 \times 0.6$ & $2 \mathrm{~d}$ & $184 \mathrm{~m}^{3} / \mathrm{d}$ & & & _. & 52 & 146 \\
\hline & [53] & HSSF & Gravel & $50 \times 13 \times 0.5$ & $6.7 \mathrm{~d}$ & $22.5 \mathrm{~m}^{3} / \mathrm{d}$ & 10 & & - & 58 & 60 \\
\hline & [54] & - & Gravel & $30 \times 3 \times 0.6$ & $15 \mathrm{~d}$ & $2000 \mathrm{l} / \mathrm{d}$ & 5 & 3.47 & - & 266 & 87.5 \\
\hline \multirow{13}{*}{$\mathrm{Zn}$} & This study & HSSF & Limestone & $1 \times 1 \times 4.1+1 \times 0.5 \times 4.1$ & $2 \mathrm{~d}$ & $5 \mathrm{~m}^{3} /$ day & 4 & 0.26 & 30.2 & 188 & 144 \\
\hline & [22] & - & Coke & $1.93 \times 0.4 \times 0.6$ & $12.68 \mathrm{~d}$ & $300 \mathrm{~mL} / \mathrm{min}$ & 2 & 48.5 & 91.18 & - & 0.1016 \\
\hline & & & $\begin{array}{c}\text { Gravel } \\
\text { Soil }\end{array}$ & $12 \times 023$ & & & & & 61.57 & & 0.009 \\
\hline & {$[27]$} & $\begin{array}{l}\text { SF } \\
\text { HSSF }\end{array}$ & $\begin{array}{l}\text { Soll } \\
\text { Limestone }\end{array}$ & $\begin{array}{l}1.2 \times 0.23 \\
1.2 \times 0.28\end{array}$ & $2 \mathrm{~d}$ & $0.05 \mathrm{~m}^{3} /$ day & 1 & 1.5 & $\begin{array}{l}78.9 \\
81.7\end{array}$ & - & - \\
\hline & [31] & HSSF & Gravel & $12 \times 2.5 \times(1.5-2)$ & - & $8 \mathrm{~m}^{3} / \mathrm{d}$ & 8 & 0.5 & 27 & 66.2 & 59.1 \\
\hline & {$[32]$} & $\mathrm{SF}$ & $\begin{array}{l}\text { Gravel and } \\
\text { sand }\end{array}$ & $1.8 \times 0.5 \times 0.5$ & $1.25 \mathrm{~d}$ & $16 \mathrm{~cm} / \mathrm{d}$ & 4 & 0.366 & 92 & 160 & 60 \\
\hline & [35] & SSP & Soil & $1 \times 2 \times 0.25$ & & & 2 & 5 & 94.2 & 302.53 & 149.56 \\
\hline & [55] & HSSF & - & - & - & - & - & - & - & 86 & 20.5 \\
\hline & [52] & - & Sediment & - & - & - & - & 516 & - & $69.6-198$ & $45.7-154.6$ \\
\hline & {$[53$} & VSSF & Goetextile & $12.5 \times 30 \times 0.6$ & $2 \mathrm{~d}$ & $184 \mathrm{~m}^{3} / \mathrm{d}$ & - & - & - & 132 & 70 \\
\hline & {$[53]$} & HSSF & Gravel & $50 \times 13 \times 0.5$ & $6.7 \mathrm{~d}$ & $22.5 \mathrm{~m}^{3} / \mathrm{d}$ & 10 & - & - & 129 & 23 \\
\hline & [54] & - & Gravel & $30 \times 3 \times 0.6$ & $15 \mathrm{~d}$ & $2000 \mathrm{~L} / \mathrm{d}$ & 5 & 0.12 & - & 46.3 & 16.6 \\
\hline & [55] & - & - & - & - & - & - & - & - & $54.99-176.7$ & $20.65-32.4$ \\
\hline
\end{tabular}


Table 4. Cont.

\begin{tabular}{|c|c|c|c|c|c|c|c|c|c|c|c|}
\hline \multirow{2}{*}{ Metals } & \multirow{2}{*}{ Authors } & \multirow{2}{*}{$\begin{array}{l}\text { Type of } \\
\text { Wetland }\end{array}$} & \multirow{2}{*}{ Substrates } & \multirow{2}{*}{ Length $\times$ width $\times$ depth $(\mathrm{m})$} & \multirow{2}{*}{$\begin{array}{l}\text { Retention } \\
\text { Time }\end{array}$} & \multirow{2}{*}{$\begin{array}{l}\text { Hydraulic } \\
\text { Loading } \\
\text { Rate }\end{array}$} & \multirow{2}{*}{$\begin{array}{l}\text { Operation } \\
\text { Duration } \\
\text { (Months) }\end{array}$} & \multirow{2}{*}{$\begin{array}{c}\text { Influent } \\
\text { Concentration } \\
(\mathrm{mg} / \mathrm{L})\end{array}$} & \multirow{2}{*}{$\begin{array}{l}\text { Removal } \\
\text { Efficiency } \\
(\%)\end{array}$} & \multicolumn{2}{|c|}{$\begin{array}{l}\text { Metal Content in P. australis } \\
(\mathrm{mg} / \mathrm{kg}-\mathrm{DW})\end{array}$} \\
\hline & & & & & & & & & & $\begin{array}{l}\text { Belowground } \\
\text { Biomass }\end{array}$ & $\begin{array}{l}\text { Aboveground } \\
\text { Biomass }\end{array}$ \\
\hline \multirow{10}{*}{$\mathrm{Cd}$} & This study & HSSF & Limestone & $1 \times 1 \times 4.1+1 \times 0.5 \times 4.1$ & $2 \mathrm{~d}$ & $5 \mathrm{~m}^{3} /$ day & 4 & 0.21 & 83.7 & 0.784 & 1.1 \\
\hline & [33] & - & PVC & $0.5 \times 0.5 \times 0.3$ & $16 \mathrm{~d}$ & - & 2 & 4.55 & 44.2 & - & 2.47 \\
\hline & [34] & - & - & $360 \mathrm{~m}^{2}$ & - & - & 4 & 1.73 & 72 & - & $0.007-0.04$ \\
\hline & [35] & SSP & Soil & $1 \times 2 \times 0.25$ & & & 2 & 0.5 & 92.2 & 33.26 & 11.42 \\
\hline & [50] & VSSF & Sand & $1 \times 1 \times 1.5$ & $2-3 w$ & $28 \mathrm{~mm} / \mathrm{d}$ & 24 & & - & 0.739 & $<0.03$ \\
\hline & [51] & HSSF & - & - & - & - & - & - & - & 0.21 & $0.57-0.9$ \\
\hline & [52] & - & Sediment & - & - & - & - & 0.1 & - & $0.2-1.3$ & $<0.1$ \\
\hline & $5[02]$ & VSSF & Goetextile & $12.5 \times 30 \times 0.6$ & $2 \mathrm{~d}$ & $184 \mathrm{~m}^{3} / \mathrm{d}$ & - & & & 0.21 & 0.014 \\
\hline & {$[33]$} & HSSF & Gravel & $50 \times 13 \times 0.5$ & $6.7 \mathrm{~d}$ & $22.5 \mathrm{~m}^{3} / \mathrm{d}$ & 10 & - & - & 0.47 & 0.083 \\
\hline & [54] & - & Gravel & $30 \times 3 \times 0.6$ & $15 \mathrm{~d}$ & $2000 \mathrm{~L} / \mathrm{d}$ & 5 & $<0.01$ & - & 0.25 & 0.05 \\
\hline \multirow{13}{*}{$\mathrm{Pb}$} & This study & HSSF & Limestone & $1 \times 1 \times 4.1+1 \times 0.5 \times 4.1$ & $2 \mathrm{~d}$ & $5 \mathrm{~m}^{3} /$ day & 4 & 0.27 & 42.8 & 115 & 80.9 \\
\hline & [22] & - & Coke & & $12.68 \mathrm{~d}$ & $300 \mathrm{~mL} / \mathrm{min}$ & - & 27.44 & 99.66 & Ele & 0.0763 \\
\hline & {$[\angle 2]$} & - & Gravel & $1.93 \times 0.4 \times 0.6$ & $9.6 \mathrm{~d}$ & $300 \mathrm{~mL} / \mathrm{min}$ & 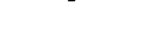 & 49.89 & 99.53 & 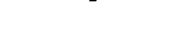 & 0.0736 \\
\hline & [27] & $\begin{array}{l}\text { SF } \\
\text { HSSF }\end{array}$ & $\begin{array}{c}\text { Soil } \\
\text { Limestone }\end{array}$ & $\begin{array}{l}1.2 \times 0.23 \\
1.2 \times 0.28\end{array}$ & $2 \mathrm{~d}$ & $0.05 \mathrm{~m}^{3} /$ day & 1 & 0.6 & $\begin{array}{l}73.5 \\
81.1\end{array}$ & - & - \\
\hline & [34] & - & - & $360 \mathrm{~m}^{2}$ & - & - & 4 & 7.58 & $\begin{array}{c}1.1 \\
69\end{array}$ & - & $36-108$ \\
\hline & [35] & SSP & Soil & $1 \times 2 \times 0.25$ & & & 2 & 2 & 96.4 & 152.88 & 54.3 \\
\hline & [50] & VSSF & Sand & $1 \times 1 \times 1.5$ & $2-3 w$ & $28 \mathrm{~mm} / \mathrm{d}$ & 24 & - & - & 17.63 & 0.98 \\
\hline & [51] & HSSF & - & - & - & - & - & - & - & 7.1 & 0.11 \\
\hline & [52] & - & Sediment & - & - & - & - & 186 & - & $9.1-79.1$ & $0.7-1.1$ \\
\hline & [53] & VSSF & Goetextile & $12.5 \times 30 \times 0.6$ & $2 \mathrm{~d}$ & $184 \mathrm{~m}^{3} / \mathrm{d}$ & - & 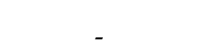 & - & 10 & 0.39 \\
\hline & [33] & HSSF & Gravel & $50 \times 13 \times 0.5$ & $6.7 \mathrm{~d}$ & $22.5 \mathrm{~m}^{3} / \mathrm{d}$ & 10 & - & - & 20 & 0.53 \\
\hline & [54] & - & Gravel & $30 \times 3 \times 0.6$ & $15 \mathrm{~d}$ & 2000 L/d & 5 & 0.06 & - & 12.2 & 0.1 \\
\hline & [55] & - & - & - & - & - & - & - & - & 21.49-90.94 & $1.14-2.18$ \\
\hline
\end{tabular}

HSSF: horizontal subsurface flow, VSSF: vertical subsurface flow, SF: surface flow, SSP: subsurface flow, ${ }^{*}$ Removal efficiency of constructed wetland combined with sorbent. 


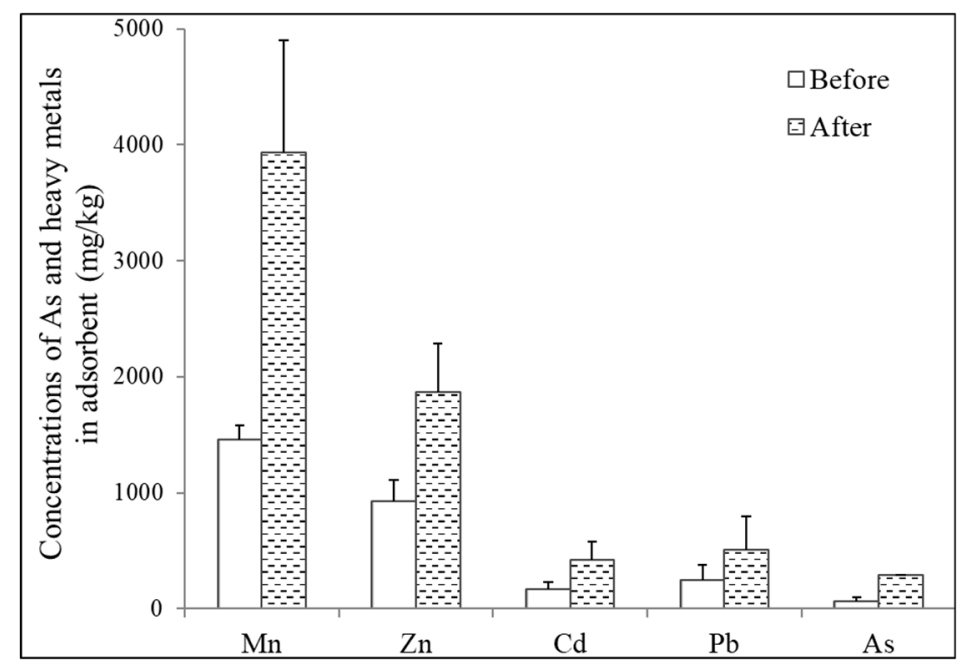

Figure 3. Concentrations of As and heavy metals in the adsorbent (mg/kg) after 4 months.

\subsection{Plant Growth and Concentrations of As and Heavy Metals in P. australis}

The plants in CWs produced shoots after 1 month, and approximately $80 \%$ of the transplanted plants grew well. The system started after 3 months of transplanting, when the average height of $P$. australis was approximately $100 \mathrm{~cm}$, and the average length of the new shoots was $25 \mathrm{~cm}$. The plant showed continuous growth during the 4 months of the experiment.

The concentrations of $\mathrm{Mn}, \mathrm{Zn}, \mathrm{Cd}, \mathrm{Pb}$, and As in P. australis after 4 months of system operation were higher than those before the experiment (Figure 4). In addition, with the exception of Zn before the experiment, the concentrations of As and heavy metals in the belowground parts of the plant were higher than those in the aboveground biomass of P. australis (Figure 4). This is consistent with the results reported by Bonanno and Giudice [56] and Nga and Ha [57]. The concentrations of Mn, Zn, Cd, $\mathrm{Pb}$, and As in the belowground parts were 194, 188, 0.78, 115, and $21.9 \mathrm{mg} / \mathrm{kg}-\mathrm{DW}$, respectively, while those in the aboveground biomass were 94.2, 144, 1.1, 80.9, and $17.8 \mathrm{mg} / \mathrm{kg}$-DW. Higher concentrations of $\mathrm{Mn}$ and $\mathrm{Zn}$ than those of the other studied metals in the plant were possibly due to Mn and $\mathrm{Zn}$ being two essential elements for plant growth, whereas $\mathrm{Zn}, \mathrm{Pb}$, and As are known to be potentially toxic elements [58]. The concentrations of $\mathrm{As}, \mathrm{Mn}, \mathrm{Zn}, \mathrm{Cd}$, and $\mathrm{Pb}$ in both belowground and aboveground parts of the plant in this study were lower than those reported by Nga and Ha [57], reflecting the differences of metal concentrations between lab experiments and a field study, as well as the impacts of the initial concentrations and retention time.

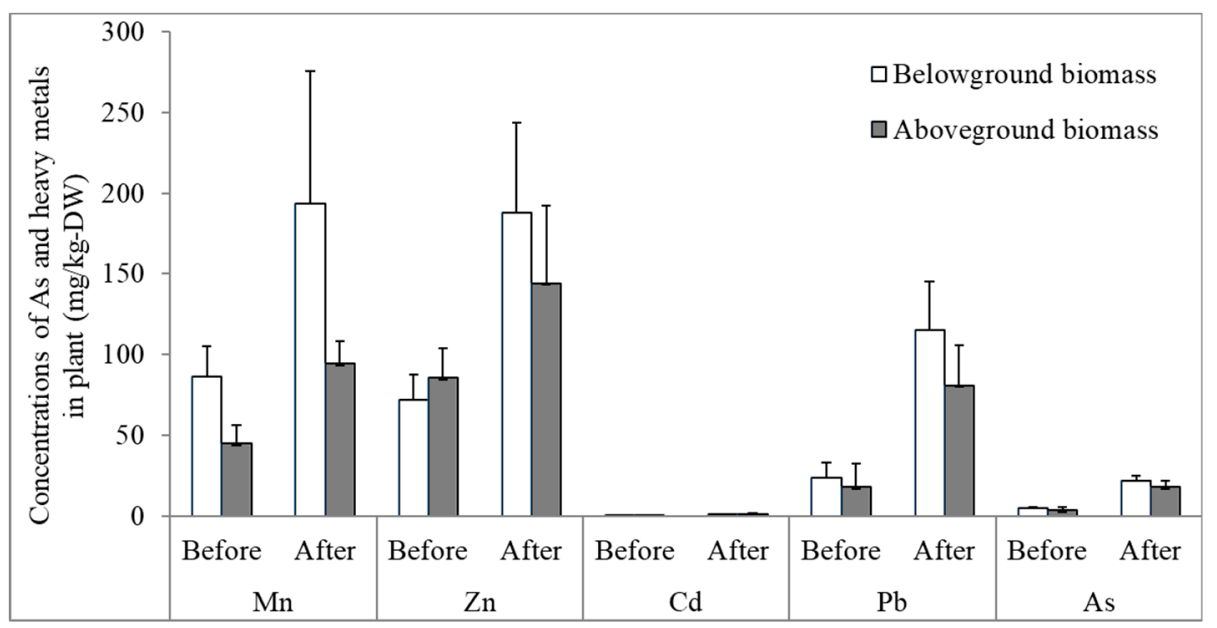

Figure 4. Accumulation of As and heavy metals in Phragmites australis (mg/kg-DW) after 4 months. 
Table 4 shows the concentrations of As and heavy metals in P. australis in CWs. Alishir et al. [49] showed higher concentration of As in the belowground parts of the plant than that found in this study. However, As concentrations in both the belowground and aboveground parts of the plant in this study were higher than those in other studies [24,49-52] (Table 4). The concentrations of Mn in all parts of the plant in this study were higher than those in previous studies [51-54] (Table 4). We obtained higher concentrations of $\mathrm{Zn}$ in the plant than other studies [22,30,32,51,53-55]; however, Liu et al. [33] and Diego et al. [52] reported higher concentrations of $\mathrm{Zn}$ in the plant (Table 4). Schierup et al. [54] reported concentrations of $\mathrm{Cd}$ in the aboveground part of the plant within 4.4-13.5 mg/kg-DW; however, Cd concentrations in the plant in this study were higher than those in other researches [35,50-54] (Table 4). This study also demonstrated high concentrations of $\mathrm{Pb}$ in $P$. australis compared to previous studies, such as Chen et al. [22], Liu et al. [33], Vymazal et al. [51], Lesage et al. [53], and Phillips et al. [55] (Table 4); however, $\mathrm{Pb}$ concentration in this plant when receiving highway runoff reached $152.88 \mathrm{mg} / \mathrm{kg}-\mathrm{DW}$ in the root [33] and $108 \mathrm{mg} / \mathrm{kg}$-DW in the aboveground biomass [35] (Table 4).

The total amounts of $\mathrm{Mn}, \mathrm{Zn}, \mathrm{Cd}, \mathrm{Pb}$, and As removed from wastewater by the $\mathrm{CWs}$ with limestone substrate after 4 months were estimated to be 773, 43.1, 70.1, 101, and $44.8 \mathrm{~g}$, respectively. The estimated biomass of P. australis in CWs was $5 \mathrm{~kg} / \mathrm{m}^{2}$ in dry weight (DW). Therefore, the amounts of Mn, $\mathrm{Zn}$, $\mathrm{Cd}, \mathrm{Pb}$, and As accumulated in the whole plant were 18.0, 20.7, 0.116, 12.3, and $2.5 \mathrm{~g}$, respectively. These values were much lower than those removed by the CWs. This result indicated that besides metal uptake and accumulation in P. australis, the processes of metal removal from CWs included adsorption to substrates, co-precipitation, filtration, and deposition in the rhizosphere [19,59]. These mechanisms of metal removal may involve the minerals present in the substrates of the CWs (Table 1) and the main sulfur minerals (e.g., sphalerite-ZnS, galena-PbS, and pyrite- $-\mathrm{FeS}_{2}$ ) of the Cho Don $\mathrm{Pb}-\mathrm{Zn}$ mine [60], which released sulfates and Fe compounds through an oxidation process.

\section{Conclusions}

The $5 \mathrm{~m}^{3} /$ day pilot-scale constant flow rate of the combined system with modified iron mine drainage sludge and constructed wetlands showed efficient removal of As and heavy metals from contaminated wastewater in the largest $\mathrm{Pb}-\mathrm{Zn}$ mine in Vietnam. The concentrations of As and heavy metals in the effluent during 4 months of the combined system operation were lower than the maximum allowable limit regulated by the QCVN 40:2011/BTNMT for industrial wastewater. The limestone substrate in CWs showed greater removal of $\mathrm{Mn}, \mathrm{Zn}, \mathrm{Cd}$, and $\mathrm{Zn}$ than the laterite substrate, whereas the latter was more efficient for As removal. Further studies need to be conducted with the combined system using higher concentrations of metals in the influent and optimal conditions for metal removal before it can be applied at full scale.

Author Contributions: H.T.H.N., H.T.C., N.T.M., and K.M.N. designed the experiment, B.Q.N., A.T.K.B., H.T.A.N., T.T.P., and T.T.D. operated the system and analysis, H.N.T.N., B.Q.N., and T.T.D. wrote the original draft, and K.-W.K. reviewed and edited the paper.

Funding: This research was funded by the National Science and Technology Program for Sustainable Development of Vietnam's Northwest Region (KHCN-TB.02C/13-18), the Vietnam National Foundation for Science and Technology Development (NAFOSTED) under grant number 105.99-2017.313, and GIST Research Institute (GRI) grant at Gwangju Institute of Science and Technology in 2019.

Conflicts of Interest: The authors declare no conflict of interest. The funders had no role in the design of the study; in the collection, analyses, or interpretation of data; in the writing of the manuscript, or in the decision to publish the results.

\section{References}

1. Gosar, M. Environmental impacts of metal mining. Mater. Geoenviron. 2004, 51, 2097-2107.

2. Chockalingam, E.; Subramanian, S. Studies on removal of metal ions and sulphate reduction using rice husk and Desulfotomaculum nigrificans with reference to remediation of acid mine drainage. Chemosphere 2006, 62, 699-708. [CrossRef] [PubMed] 
3. Gunatilake, S.K. Methods of removing heavy metals from industrial wastewater. J. Multidiscip. Eng. Sci. Stud. 2015, 1, 12-18.

4. Chakravarti, A.K.; Chowdhury, S.B.; Chakrabarty, S.; Chakrabarty, T.; Mukherjee, D.C. Liquid membrane multiple emulsion process of chromium(VI) separation from wastewaters. Colloids Surf. A Physicochem. Eng. Asp. 1995, 103, 59-71. [CrossRef]

5. Hering, J.G.; Chen, P.J.; Wilkie, J.A.; Elimelech, M. Arsenic removal from drinking water during coagulation. J. Environ. Eng. 1997, 8, 800-807. [CrossRef]

6. Kim, J.; Benjamin, M.M. Modeling a novel ion exchange process for arsenic and nitrate removal. Water Res. 2004, 38, 2053-2062. [CrossRef] [PubMed]

7. Kumar, P.R.; Chaudhari, S.; Khilar, K.C.; Mahajan, S.P. Removal of arsenic from water by electrocoagulation. Chemosphere 2005, 55, 1245-1252. [CrossRef]

8. Katsoyiannis, I.A.; Zouboulis, A.I. Removal of arsenic from contaminated water sources by sorption onto Iron-coated polymeric materials. Water Res. 2002, 36, 5145-5155. [CrossRef]

9. Aksu, Z. Determination of equilibirium, kinetic and thermodynamic parameters of the batch biosorption of nickel (II) ions onto Clorella vulgaris. Process Biochem. 2002, 38, 89-99. [CrossRef]

10. Amarasinghe, B.M.; Williams, R.A. Tea waste as a low cost adsorbent for the removal of $\mathrm{Cu}$ and $\mathrm{Pb}$ from wastewater. Chem. Eng. J. 2007, 132, 299-309. [CrossRef]

11. Ali, I.; Asim, M.; Khan, T.A. Low cost adsorbents for the removal of organic pollutants from wastewater. J. Environ. Manag. 2012, 113, 170-183. [CrossRef] [PubMed]

12. Patel, H.; Vashi, R.T. COD and BOD removal from Textile wastewater using naturally prepared adsorbents and their activation forms using sulphuric acid. Wastewater Engineering: Advanced Wastewater Treatment Systems. IJSR Publ. 2014, 31-40.

13. Hegazi, H.A. Removal of heavy metals from wastewater using agricultural and industrial wastes as adsorbents. HBRC J. 2013, 9, 276-282. [CrossRef]

14. Ahmaruzzaman, M. Industrial wastes as low-cost potential adsorbents for the treatment of wastewater laden with heavy metals. Adv. Colloid Interface Sci. 2011, 166, 36-59. [CrossRef] [PubMed]

15. Iakovleva, E.; Sillanpaa, M. The use of low-cost adsorbents for wastewater purification in mining industries. Environ. Sci. Pollut. Res. 2013, 20, 7878-7899. [CrossRef]

16. Yu, X.; Zhu, L.; Guo, B.; He, S. Adsorption of mercury on laterite from Guizhou Province, China. J. Environ. Sci. 2008, 20, 1328-1334. [CrossRef]

17. Chen, T.Y.; Kao, C.M.; Yeh, T.Y.; Chien, H.Y.; Chao, A.C. Application of a constructed wetland for industrial wastewater treatment: A pilot-scale study. Chemesphere 2006, 64, 497-502. [CrossRef]

18. Vymazal, J. Constructed wetlands for wastewater treatment. Water 2010, 2, 530-549. [CrossRef]

19. Vymazal, J.; Brezinova, T. Accumulation of heavy metals in aboveground biomass of Phragmites australis in horizontal flow constructed wetlands for wastewater treatment: A review. Chem. Eng. J. 2016, 290, $232-242$. [CrossRef]

20. Masi, F.; Rizzo, A.; Regelsberger, M. The role of constructed wetlands in a new circular economy, resource oriented, and ecosystem services paradigm. J. Environ. Manag. 2017, 216, 275-284. [CrossRef]

21. Jiang, X.; Wanga, C. Zinc distribution and zinc-binding forms in Phragmites australis under zinc pollution. J. Plant Physiol. 2008, 165, 697-704. [CrossRef]

22. Chen, M.Z.; Tang, Y.Y.; Li, X.P.; Yu, Z.X. Study on the heavy metals removal efficiencies of constructed wetlands with different substrates. J. Water Resour. Prot. 2009, 1, 22-28. [CrossRef]

23. Zhu, W.L.; Cui, L.H.; Ouyang, Y.; Long, C.F.; Tang, X.D. Kinetic adsorption of ammonium nitrogen by substrate materials for constructed wetlands. Pedosphere 2011, 21, 454-463. [CrossRef]

24. Allende, L.K.; McCarthy, D.T.; Fletcher, T.D. The influence of media type on removal of arsenic, iron and boron from acidic wastewater in horizontal flow wetland microcosms planted with Phragmites australis. Chem. Eng. J. 2014, 246, 217-228. [CrossRef]

25. Ha, N.T.H.; Sakakibara, M.; Sano, S. Accumulation of Indium and other heavy metals by Eleocharis acicularis: An option for phytoremediation and phytomining. Bioresour. Technol. 2011, 102, 2228-2234. [CrossRef] [PubMed]

26. Nguyen, K.M.; Nguyen, B.Q.; Nguyen, H.T.; Nguyen, H.T.H. Adsorption of arsenic and heavy metals from solutions by unmodified iron-ore sludge. Appl. Sci. 2019, 9, 619. [CrossRef] 
27. Ha, N.T.H.; Anh, B.T.K. The removal of heavy metals by iron mine drainage sludge and Phragmites australis. IOP Conf. Ser. Earth Environ. Sci. 2017, 71, 012-022.

28. Thao, N.H.P.; Ha, N.T.H.; Thuy, P.T.; Khai, N.M.; Nga, T.T.H. The sorption ability of Tam Duong and Thach That laterite in the treatment of heavy metals and arsenic. Vnu J. Sci. Earth Sci. 2016, 32, 321-326.

29. QCVN40: 2011-BTNMT Vietnam National Technical Regulation on Industrial Wastewater Quality. Available online: https://moitruong.com.vn/Upload/48/Nam_2017/Thang_3/Ngay_3/QCVN40-2011-BTNMT. pdf (accessed on 24 November 2018).

30. Renugadevi, N.; Sreeja, M.; Lalitha, P. Kinetics of chromium(IV) removal from aqueous solution by adsorption technique using activated carbon from pods of wood apple. J. Ultra Chem. 2010, 6, 27-34.

31. Alessio, G.; Paola, V.; Ezio, R. Removal and accumulation of $\mathrm{Cu}, \mathrm{Ni}$, and $\mathrm{Zn}$ in horizontal subsurface flow constructed wetlands: Contribution of vegetation and filling medium. Sci. Total Environ. 2010, 408, 5097-5105.

32. Yeh, T.Y.; Chou, C.C.; Pan, C.T. Heavy metal removal within pilot-scale constructed wetlands receiving river watẻ contaminated by confined swine operations. Desalination 2009, 249, 308-373. [CrossRef]

33. Liu, J.; Dong, Y.; Xu, H.; Wang, D.; Xu, J. Accumulation of Cd, Pb and $\mathrm{Zn}$ by 19 wetland plant species in constructed wetland. J. Hazard. Mater. 2007, 147, 947-953. [CrossRef] [PubMed]

34. Kumari, M.; Tripathi, B.D. Effect of Phragmites australis and Typha latifolia on biofiltration of heavy metals from secondary treated effluent. Int. J. Environ. Sci. Technol. 2013, 12, 1029-1038. [CrossRef]

35. Scholes, L.N.L.; Shutes, R.B.E.; Revitt, D.M.; Purchase, D.; Forshaw, M. The removal of urban pollutants by constructed wetlands during wet weather. Water Sci. Technol. 1999, 40, 333-340. [CrossRef]

36. Jiang, M.; Wang, Q.; Jin, X.; Chen, Z. Removal of Pb (II) from aqueous solution using modified and unmodified kaolinite clay. J. Hazard. Mater. 2009, 170, 332-339. [CrossRef] [PubMed]

37. Jiang, W. Arsenate and cadmium co-adsorption and co-precipitation on goethite. J. Hazard. Mater. 2013, 262, 55-63. [CrossRef]

38. Raul, P.K.; Devi, R.R.; Umlong, I.M.; Thakur, A.J.; Banerjee, S.; Veer, V. Iron oxide hydroxide nanoflower assisted removal of arsenic from water. Mater. Res. Bull. 2014, 49, 360-368. [CrossRef]

39. Glocheux, Y.; Pasarin, M.M.; Albadarin, A.B.; Allen, S.J.; Walker, G.M. Removal of arsenic from groundwater by adsorption onto an acidified laterite by-product. Chem. Eng. J. 2013, 228, 565-574. [CrossRef]

40. Pehlivan, E.; Tran, H.T.; Ouédraogo, W.K.I.; Schmidt, C.; Zachmann, D.; Bahadir, M. Sugarcane bagasse treated with hydrous ferric oxide as a potential adsorbent for the removal of $\mathrm{As}(\mathrm{V})$ from aqueous solutions. Food Chem. 2013, 138, 133-138. [CrossRef]

41. Vieira, B.R.C.; Pintor, A.M.A.; Boaventura, R.A.R.; Botelho, C.M.S.; Santos, S.C.R. Arsenic removal from water using iron-coated seaweeds. J. Environ. Manag. 2017, 192, 224-233. [CrossRef]

42. Ramana, D.K.V.; Jamuna, K.; Satyanarayana, B.; Venkateswarlu, B.; Rao, M.M.; Seshaiah, K. Removal of heavy metals from aqueous solutions using activated carbon prepared from Cicer arietinum. Toxicol. Environ. Chem. 2010, 92, 1447-1460. [CrossRef]

43. Gupta, S.S.; Bhattacharyya, K.G. Immobilization of $\mathrm{Pb}$ (II), Cd (II) and Ni (II) ions on kaolinite and montmorillonite surfaces from aqueous medium. J. Environ. Manag. 2008, 87, 46-58. [CrossRef] [PubMed]

44. Giménez, J.; De Pablo, J.; Martínez, M.; Rovira, M.; Valderrama, C. Reactive transport of arsenic (III) and arsenic (V) on natural hematite: Experimental and modeling. J. Colloid Interface Sci. 2010, 348, $293-297$. [CrossRef] [PubMed]

45. Donald, L.S. Environmental Soil Chemistry, 2nd ed.; Academic Press: London, UK, 2003; ISBN 0126564469.

46. Lata, S.; Singh, P.K.; Samadder, S.R. Regeneration of adsorbents and recovery of heavy metals: A review. Int. J. Environ. Sci. Technol. 2015, 12, 1461-1478. [CrossRef]

47. Wambu, E.W.; Muthakia, G.K.; Shiundu, P.M.; Thiongo, K.J. Kinetics of copper desorption from regenerated spent bleaching earth. Am. Eurasian J. Sci. Res. 2009, 4, 317-323.

48. Jalali, R.; Ghafourian, H.; Asef, Y.; Davarpanah, S.J.; Sepeh, S. Removal and recovery of lead using nonliving biomass of marine algae. J. Hazard. Mater. 2002, 92, 253-262. [CrossRef]

49. Alishir, A.; Mohammad, M.; Abdolmajid, L.; Ebrahim, P.; Hossein, S. Mercury and arsenic accumulation by three species of aquatic plants in Dezful, Iran. Afr. J. Agric. Res. 2011, 6, 5391-5397. [CrossRef]

50. Ye, Z.H.; Baker, A.J.M.; Wong, M.H.; Willis, A.J. Zinc, lead and Cadmium tolerance, Uptake and Accumulation by the Common reed, Phragmites australis (Cav.) Trin. Ex Steudel. Ann. Bot. 1997, 80, 363-370. [CrossRef] 
51. Vymazal, J.; Lenka, K.; Jaroslav, S.; Vladislav, C.; Jana, S. Trace elements in Phragmites australis growing in constructed wetlands for treatment of municipal wastewater. Ecol. Eng. 2009, 35, 303-309. [CrossRef]

52. Diego, C.F.; Manuel, P.F.; Jose, A.E.; Blanca, A.L. Long-term (two annual cycles) phytoremediation of heavy metal- contaminated estuarine sediments by Phragmites australis. New Biotechnol. 2016, 38, 56-64.

53. Lesage, E.; Rousseau, D.P.L.; Meers, E.; Tack, F.M.G.; Pauw, N.D. Accumulation of metals in a horizontal subsurface flow constructed wetland treating domestic wastewater in Flanders, Belgium. Sci. Total Environ. 2007, 380, 102-115. [CrossRef] [PubMed]

54. Schierup, H.H.; Larsen, V.J. Macrophyte cycling of zinc, copper, lead and cadmium in the littoral zone of a polluted and non-polluted lake. I. Availability, uptake, and translocation of heavy metals in Phragmites australis (Cav.) Trin. Aquat. Bot 1981, 11, 197-210. [CrossRef]

55. Phillips, D.P.; Human, L.R.D.; Adams, J.B. Wetland plants as indicators of heavy metal contamination. Mar. Pollut. Bull. 2015, 92, 227-232. [CrossRef] [PubMed]

56. Bonanno, G.; Giudice, R.L. Heavy metal bioaccumulation by the organs of Phragmites australis (common reed) and their potential use as contamination indicators. Ecol. Indic. J. 2009, 10, 639-645. [CrossRef]

57. Nga, T.T.H.; Ha, N.T.H. Simultaneous removal of some heavy metals and arsenic from aqueous solutions by Phragmites australis. Vietnam J. Sci. Technol. 2016, 54, 259-264.

58. Selinus, O.; Alloway, B.J.; Centeno, J.A.; Finkelman, R.B.; Fuge, R.; Lindh, U.; Smedley, P. Essentials of Medical Geology: Impacts of the Natural Environment on Public Health; Elsevier Academic Press: London, UK, 2005.

59. Marchand, L.; Mench, M.; Jacob, D.L.; Otte, M.L. Metal and metalloid removal in constructed wetlands, with emphasis on the importance of plants and standardized measurements: A review. Environ. Pollut. 2010, 158, 3447-3461. [CrossRef]

60. Anh, T.T.; Gaskov, I.V.; Hoa, T.T.; Nevolko, P.A.; Dung, P.T.; Nien, B.A.; Can, P.N. Mineralogical and geochemical characteristics and forming conditions of lead-Zinc deposits in Lo Gam structure, northern Vietnam. Vietnam J. Earth Sci. 2011, 33, 393-408. (In Vietnamese)

(C) 2019 by the authors. Licensee MDPI, Basel, Switzerland. This article is an open access article distributed under the terms and conditions of the Creative Commons Attribution (CC BY) license (http://creativecommons.org/licenses/by/4.0/). 